\title{
The connotation of legitimacy and the historical evolution of Western political
}

\author{
Jianping LIU \\ Sichuan Agricultural University \\ Sichuan, China
}

\begin{abstract}
- the concept of "legitimacy" is the core of political theory, it born with the country, but find the systematic analysis about legitimacy theory starts from modern. In the process of research, scholars have gradually clear the concept of political legitimacy, and differentiate these two concepts of legitimacy and law. At the same time, since ancient Greece, in the different historical period, the study of political legitimacy theory has different content and features, among them, with these two factions: western modern normative theory and empirical theory as representatives. Here, this paper was on the basis of historical materials, combing the development of western political legitimacy, straightening out the relationship between legitimacy and the law, finding out the essential connotation of political legitimacy.
\end{abstract}

Keywords- political legitimacy; law; normative theory; empirical theory;

\section{INTRODUCTION}

\section{A. The concept of political legitimacy}

The law divides into broad sense and narrow sense, broad sense refers to the order of the whole society, narrow sense only refers to the order of political rule, namely political legitimacy. This article is talking about the latter.

The word "legitimacy" first appeared in medieval literature, before the Middle Ages, though the scholars did not clearly put forward the concept of "legitimacy", but this concept is always there, as early as it refers to the "law". Until after the Middle Ages, the idea of "legitimacy" began with a close connection with power, political rule. In modern times the earliest scholar who made a systematic interpretation of legitimacy theory is Rousseau. He clearly put forward the "public will" is the basis of maintaining political orders in the "social contract". He said: "man is born free, but everywhere is in chains. Someone who flatters himself as the master of everything else, instead, more slaves than anything else. How to form this kind of change? I don't know. What makes this change become legal?" At last he found the answer: on the basis of public will, to unify the obligations and rights, to form his said" people's sovereignty". "Only the public can create the purpose in accordance with the country, namely public happiness, to guide all kinds of national forces." Citizens obey the country's political rule, and the power comes from the consent of the people of the country, so the citizen is, in fact, in obedience to his own will. Therefore, Rousseau was in good coordination with the relationship between freedom and obedience these two subjects.

Modern German sociologist Max Weber has made a systematic demonstration for legitimacy. He thinks the problem of political legitimacy that needed to be solved is the "How to make political rule stable or how to political order make persist ". Weber, the angle of his research of political legitimacy is not only to analyze from the perspective of political science, as one of the founders of classical sociology, he would integrate the methods of sociology research into the political legitimacy theory, makes it of his own. He, started from the perspective of the personal social action, divided the social action into four types: instrumental rationality and value rationality, emotional (especially emotion), the traditional. At the same time, the causes of legitimacy order was divided into four categories: traditional, emotional belief, value rational belief, written laws and regulations. In the end, he divided authority into three types: legal authority, traditional authority, charismatic authority. It is said that political legitimacy has three basses: a rational basis, traditional basis, charismatic basis. Among these three types of pure, Webber himself was very positive of the legal authority based on legal principles.

In addition to Webber had discussed law systematically Jaen. Marc. Quark also had made an explanation on legitimacy; he thinks "legitimacy is admission of the rights on the rule. From this perspective, it tries to solve a basic political problem, while the solution is to prove both political power and obedience."

Generally speaking, the modern sense of law is mainly refers to the problem of how to make political order stable, how the political system to get agreed with its members, or how a political rule to get its members to obey the command, is the political system, built on the basis of voluntary compliance interactive relations between the ruler and the ruled.

\section{B. The legitimacy and the law.}

To clarify the relationship of legitimacy and law, we must make a depth analysis in the two English words. One is Legitimacy and Law. The former is more for legitimacy, emphasis on the legitimacy evaluation of a law or political order. The latter is more translated into law, said in a certain behavior under law or order whether conform to the provisions of the law.

Legitimacy is a word first appeared in the literature of the middle ages, before the middle ages, there is no explanation of legitimacy, but there are some words related to the 
legitimacy, such as the "legitimate" in the ancient Latin, it refers to the legal, consistent with the law. After the middle ages, the concept of "legitimacy" still retains the meaning of "legal", but its political characteristics were strengthened. It is more and more linked to concepts such as power, political order. Max Webber divided reasonable control into three types: traditional theory, legal theory, charm theory. In these three types, legal theory is his favorite type. Because the authority of legitimacy is based on rational laws and regulations, people are not a habit of obedience, not someone, but the impersonality legal order. Weber's legitimacy is based on the convolution of law belief. As Carl Schmitt said, law has become a form of legitimacy, rather than it's opposite.

In Weber's view, the legitimacy is the necessary condition of law, his kind of tool rationalism's essence is casting aside the value and significance of the law itself, just talking about the form of law. Jaen. Marc. Quark thinks that cannot simply boil down the legitimacy to the law, legitimacy in addition to be "favorable" to this condition, there should be "normative "to this condition, which is said that the standard of value judgment, this is the criticism of Jaen. Marc. Quark. to Webber. In Jaen. Marc. Quark's opinion, legitimacy is not confined to the legal level, only has the law does not enough to establish the rule of right. The legitimacy cannot constitute an independent law, is only a kind of index of legitimacy. Therefore, in order to allow law to make efforts on legitimacy, you need to find other conditions for the law, let they can constitute of the independent legitimacy. The other conditions include: "first of all, the account of the relevant laws must be coordinated with social identity constructive value... secondly; legal statements must promote the realization of social value in a credible way."

In general, the law is one of the conditions of legitimacy; to make law has efforts on legitimacy, to make the law coordinated with the value of those rulers recognized and ultimately achieve the unification of the law and legitimacy.

\section{THE HISTORICAL EVOLUTION OF THE WESTERN POLITICAL LEGITIMACY THEORY}

\section{A. Political legitimacy theory of ancient Greece period}

Ancient Greece is the gestation period of political legitimacy theory, although this time has not a scholar formally put forward the concept of legitimacy, but the political thinkers such as Plato, Aristotle leaves the thought laid a solid theoretical basis on the later political legitimacy theory research.

What the ancient Greek political thinkers concern is the political life of city-states, Plato and Aristotle, for example, through their researches about the essence of the city, the purpose of the polis, the exploration of polis regime, we can clearly touch to their political legitimacy ideology. Plato thinks that so-called the justice of the city is that people do their jobs, dutiful, not overstepping their boundaries, it is the justice of the city-state. Aristotle said that "human nature is the animal tends to city life." Human nature can only be reflected in the city life, and the city have a duty to offers all kinds of safeguard to realize the human's good karma, the rulers should rule for the public happiness of the community, this is the purpose of the city and the highest good, also is the justice of the polis.

In general, the political legitimacy theory of ancient Greece period did not differ from ethical, from Socrates' "knowledge is virtue", to Aristotle's "good" in the city state, penetrates the moral and ethical standards' efforts on ideas of legitimacy.

\section{B. The political legitimacy thought of the middle ages}

Political legitimacy theory during the middle ages has been constrained by Christian theology, has not been smooth development. Politics is a sojourner in theology, as the handmaiden of theology. But we can still find it, the flame of legitimacy thought.

Thomas Aquinas is a representative figure of medieval scholasticism, his political legitimacy theory inherited Aristotle's point of view, can also be said to be the correction of Aristotle's political philosophy. Thomas Aquinas believed the state is the product of human's rational, is the guarantee people in order to achieve a better life, maintain common interests. Rulers must take efforts to meet the common needs of the people, as he puts it: "if a free society is under the governance of the ruler who seeks happiness for the public, this is the political justice, is suitable for free." But when talking about the relationship between state and church, Aquinas believed that human's reason comes from god's reason, so the country produced by people's rational naturally under the church's control, he was under the premise of persisting the magisterial rights higher than common rights, demonstrates the rationality and necessity of secular state. As a result, the legitimacy conditions of the political rule include two things: one is seeking for the welfare of the public. The second is magisterial rights higher than the common rights.

Slightly Marcy medieval another political thinkers also inherited Aristotle's ideas of political legitimacy, he thinks the purpose of state is to realize the good life of citizens, the duty of the state is not merely exists in punishing illegal acts, more important is to help people realize the good life. Unlike Aquinas, slightly Marcy started to make political cast off the yoke of the theology, he think people can get real happiness without relying on god. At the same time, when he explores the influence of power, slightly Marcy puts forward the idea of people power. He thought the state power belongs to the legislators, but the law ultimately comes from the people, therefore, the power of the country should also belong to the people. Because of this, political rule can get the recognition and support of the people, and then the political rule has its legitimacy. The original power thought of people's had a profound impact on the modern theory of political legitimacy.

\section{The western modern political legitimacy thought}

After the middle ages, the western study of political legitimacy theory are mainly composed of two groups, one is of the empirical school represented by Max Webber, another is the reconstruction of normative school represented by Habermas, the latter not only inherits the classical normative 
concept of value judgment, but also make its further development.

First of all, is the empirical school represented by Max Webber. It is based on observed facts, considering the political legitimacy as a public recognition and obedience of political domination, paying attention to what is "real" problem, less on the specification problems about the values of the political rule itself. Its representative has Max Webber, Parsons, Seymour limpest, Easton, etc.

Weber believed that political legitimacy is the motivation that led some people to obey some commands, he divided the legitimacy foundation into three categories: one is the traditional foundation. The second is the Charisma type foundation. The third one is the legal foundation. The rule based on illegal reason type is the legitimacy. Parsons, limpest etc are based on Weber's legitimacy theory. They believe that political legitimacy problem is mainly about the problem of "how to establish the rule", their answer is, "agreed and rule".

Second is reconstruction of normative school represented by Habermas. The normative theory of legitimacy since the western modern times has two stages, one is the delegates with social contract theorists' early normative theory of legitimacy, and another is the delegates with Habermas' reconstruction of normative theory of legitimacy. Rousseau is the behalf of social contract; he is on the basis of contract theory, think that the birth of the country and the existing legitimacy foundation exists in concluding a contract between people. His legitimacy theory concentrated in embodying the people's sovereignty on the basis of the common will. Habermas not only inherited the view on the basis of the classical normative school, but also made an appropriate revision to it. He is trying to find a connection between normative and empirical, on the one hand, emphasizes the value significance of legitimacy theory, on the other hand, he is not only confined to the abstract value standard. At the same time, he further questioning the source of the value. He thinks that value is derived from the empirical facts, he put the value judgment into the history, that is to say, the standard of values will change with the change of history, and it is developing.

There is a difference of value rationality between the empirical school Represented by Webber and the normative school represented by Habermas, and the combination of practical sense.

\section{CONCLUSIONS}

WHEN THEY SEE THE CRISIS OF LATE CAPITALISM CIRCUMSTANCES, HABERMAS THINKS THE COMPLETELY COPY OF CLASSICAL NORMATIVE PARADIGM DOES NOT WORK. SO, SCHOLARS REPRESENTED BY HABERMAS, SUCH AS RAWLS, KEANE, PUTS FORWARD THE IDEA OF PUBLIC RATIONAL AND DIVERSIFIED IDEA. HABERMAS ARGUES THAT THE REAL LEGITIMACY SHOULD MAKE A CITIZEN'S RIGHT TO GET EQUAL IMPRESSED AND FULLY IMPLEMENTED; THE SPECIFIC IMPLEMENTATION IS DELIBERATIVE DEMOCRACY. CITIZENS ACCORDING TO THE PUBLIC DOMAIN PROBLEMS, AGREED TO COMMUNICATION SUCH AS DEBATE, FIND THE VALUE OF LEGITIMACY STANDARD BY THIS PRACTICAL MEAN. AS A RESULT, HIS THEORY BOTH CONTAINS THE NORMATIVE VALUE RATIONALITY AND THE EMPIRICAL FACTS.

In general, the normative theory of legitimacy is talking the problem about "what kind of rule should be set up"; the answer is the rule of "general will". They inherited tradition of the classical normative pay attention to the value content of the legitimacy, criticized the empirical school by just relying on people to obey the legal rule.

\section{References}

[1] Rousseau ,He Zhaowu. Social contract theory [M]. The commercial press, 1987.

[2] Max weber, Yan Kewen. Economic and society (volume 1) [M]. Shanghai people's publishing house, 2009

[3] Habermas, Liu Beicheng, Wei Dongcao. Legal crisis [M]. Shanghai people's publishing house, 1999.

[4] Tian Mingyue. Political legitimacy question research [M]. China social sciences press, 2006.

[5] (France) Jaen. Marc. Quarks. Legitimacy and political [M]. Central compilation press, 2002.

[6] Ma Qinghuai. Aquinas political works [M]. The commercial press, 1963.

[7] Parsons, Xiang Yangliang. The structure and process of modern society [M]. Guang Ming daily press, 1988.

[8] Tang Fenghe. The legitimacy of modernity under - based on Weber's study [J]. Journal of theoretical issue, 2011 (9).

[9] Wang Kun. Instrumental rationality and value rationality -understanding of Weber's sociology thought $[\mathrm{J}]$. Gan $\mathrm{Su}$ social science, 2005 (1).

[10] Shang Mei. the government under the rule of law: the rule of law and the government's constitutional integration $[\mathrm{J}]$. Journal of huazhong agricultural university social sciences, 2011 (3). 